\title{
Prospect of Utilization of Modular Refinery to Solve Emerging Problems in Nigeria Petroleum Industry
}

\author{
Udonne JD and Akinyemi OP* \\ Department Of Chemical and Polymer Engineering, Lagos State University, Nigeria
}

Submission: January 16, 2018; Published: February 16, 2018

*Corresponding author: Akinyemi OP, Department of Chemical and Polymer Engineering, Lagos State University, Epe Campus, Lagos, Nigeria,

Email: udonne.joseph@gmail.com

Abstract

The challenges in Nigeria oil industry with respect to demand and supply of petroleum products is of great concern in recent times. All the existing conventional refineries in the country are performing far below expectation due to old age. The utilization of modular refineries are being considered in various quarters. The prospect of using modular refineries to tackle these challenges are considered in this paper. The establishment of modular refineries within the range of $5,000 \mathrm{bpsd}$ to $30,000 \mathrm{bpsd}$ capacities by private investors should vigorously be encouraged by the Federal government and be given environment that is conducive to thrive.

\section{Introduction}

Table 1: Capacities of the major Nigeria refineries (NNPC, 2017).

\begin{tabular}{|c|c|c|}
\hline Refinery & $\begin{array}{c}\text { Installed Capacity/ } \\
\text { Bpsd }\end{array}$ & $\begin{array}{c}\text { Producing Capacity as at } \\
\text { October 2017 /Bpsd }\end{array}$ \\
\hline PHRC- 1 & 60,000 & $65,940(31.4 \%)$ \\
\hline PHRC-2 & 150,000 & \\
\hline KRPC & 110,000 & $11,110(10.1 \%)$ \\
\hline WRPC & 125,000 & $0.00(0.0 \%)$ \\
\hline Total & 445,000 & $77,050(17.31 \%)$ \\
\hline
\end{tabular}

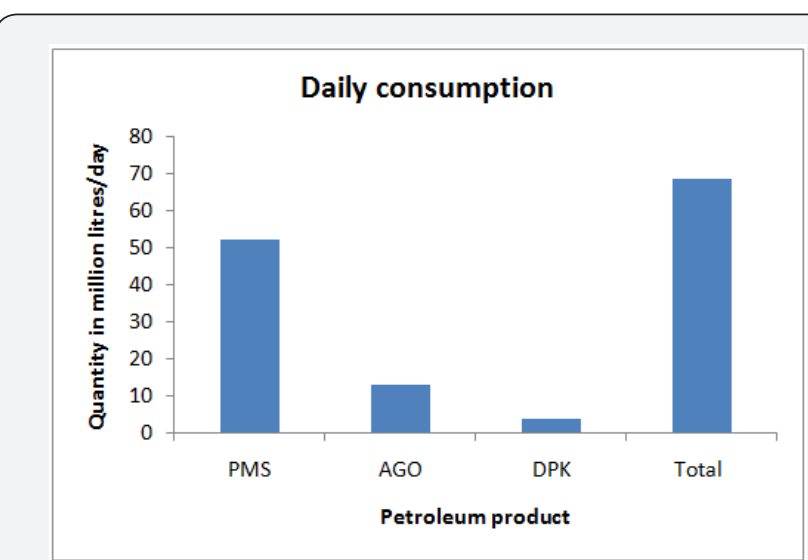

Figure 1: Daily consumption of petroleum products in Nigeria (NBS, 2016).
In spite of the four petroleum refineries owned and operated by the Nigerian Federal government in Kaduna, Warri and Port Harcourt, (two in Port Harcourt (PHRC), and one each in Kaduna (KRPC) and Warri (WRPC)), the nation surprisingly still depend on importation of close to $90 \%$ of her requirement of petroleum products $[1,2]$. The refineries have a combined installed capacity of 445,000 bpd with combined installed capacity of the two refineries of PHRC having the highest of 210,000 bpsd (Table 1). Over the last four decades, Nigeria has consistently struggled to keep its refineries functioning optimally. As at December 2017, the three refineries were still producing at combined capacity of less than $20 \%$ (Table 1). As a result of these, scarcity of petroleum products have been a reoccurring event in the recent times. The consequences of fuel scarcity are multiple: insecurity, disruption of economic activities, political instability, suffering of the citizenry among others. With population rising day by day, with about 200 million presently, the demand for petroleum products especially PMS is increasing at a very fast rate. The current demand statistics for the products is shown in Figure 1 and it is estimated that by the year 2020, the aggregate Nigeria demand will be equivalent to $800,000 \mathrm{bpsd}$ refining capacity [3]. The importation of PMS into the Nigeria market is currently above 35 million liters per day (Figure 2) and the NNPC is intending to increase this in the early part of 2018 to alleviate the suffering of the masses resulting from the fuel scarcity. It was however observed that the average importation of DPK in October 2017 
was less than that which was locally produced, the fact remains that certain quantity was still imported and t---he product was grossly in short supply to the demand of the consumers. The need to tackle these problems in the Nigeria oil industry headlong is long overdue. The so much talked about modular refineries should be given greater attention now. This paper considered the prospect of operation of the modular refineries in Nigerian oil industry to tackle these problems.

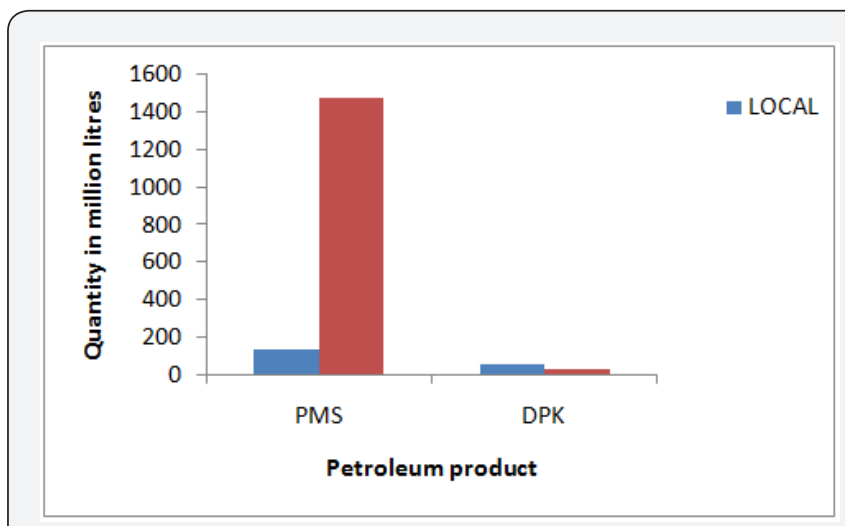

Figure 2: Comparison of locally produced to imported petroleum product in October 2017(NNPC , 2017).

\section{Modular Refinery}

A modular petroleum refinery is essentially a process plant for refining crude oil that is engineered and constructed on largely skid-mounted structures. Each skid contains a section of the entire process plant and through inter-connecting piping the component skids are linked together to form an integrated operable process plant at the site. A modular skid unit houses a process system within a frame so that the system can be transported easily. The modular refineries are usually available in capacities ranging from 1,000 to 30,000 barrels per day (bpd). The modular process skid offers a high level of quality control, efficient use of space and pre-delivery te--sting to ensure ultimate functionality. Additional advantages include fast installation and easy system accessibility. Quality fabrication teams know that putting this kind of self-contained process in place makes the work day go much more smoothly for everyone involved. A modular skid unit is often the perfect solution if only a small space is available because it arrives at the jobsite pre-assembled and contained within a frame. The unit arrives as a single piece or as multiple pieces that can be connected. Since all the system parts are housed within a set frame, the entire unit can easily be moved from one location to another if necessary [3-5].

\section{Prospects}

Modular refinery which is ideal for stranded production fields and remote locations could be sited in the riverine areas where accessibility to the petroleum products at present seems to be very difficult due to logistics. This will opportune the dwellers in such areas to purchase the products at cheaper price than what is obtainable there at present. Since modular refinery can be put together within a short time span of about 15 to 20 months for modular refinery of $20,000 \mathrm{bpsd}$, it will be easy to establish as many as possible through different investors within short period of time at different locations. This will remove the need for expensive transportation of crude oil through pipeline covering long distance which may be susceptible to vandalization as it has been experienced severally in the country. Furthermore, establishment of many modular refineries in Nigeria will bring about rapid production of feedstocks for downstream petrochemical plants $[6,7]$.

\section{Conclusion}

The establishment of modular refineries within the range of 5,000 bpsd to 30,000 bpsd capacities by private investors should vigorously be encouraged by the federal government and be given environment that is conducive to thrive. Their locations should be encouraged to be widespread across different geographical zones of the country. Complete deregulation of the downstream sector of the oil industry should be given top priority now since this will further encourage the already licensed private investors to spring into action in earnest. However, the quality of the petroleum products to be produced by the various refineries, either modular or conventional should be adequately monitored to ensure products of international standard are released into the Nigeria market space and export. Each modular refinery should be located where there are enough spaces for expansion in the nearest future since there is possibility of upgrading of production capacity of modular refinery with ease at cheap cost.

\section{References}

1. National Bureau of Statistics, NBS (2016) Petroleum Products Consumption Statistics Q1 - Q3 2016National Bureau of Statistics.

2. Nigerian National Petroleum Corporation, NNPC (2017) Monthly report: Financial and operations report for October 2017.

3. Ogbuigwe A (2016) Commercial Prospects for Modular and Full-scale Refineries. Paper presented at "Offshore Trading \& logistic Expo in Lagos on October.

4. Oloruntobiloba A (2017) Modular refineries: How Nigeria will exit nations massively import petrol- Price water house coopers, Daily Vanguard, December.

5. Michael E (2017) Appriopriate price for petrol, modular refinery in N-Delta and illegal refineries' fears. Daily Vanguard, May, Nigeria.

6. Ikenna I (2016) Modular refining as Alternative in Emerging Economies, This Day, August.

7. Emmanuel IK (2016) Modular refineries: A short-term solution to boost Nigeria's energy needs and the naira, Financial Nigeria, February. 
(C) This work is licensed under Creative

\section{Your next submission with Juniper Publishers} will reach you the below assets

- Quality Editorial service

- Swift Peer Review

- Reprints availability

- E-prints Service

- Manuscript Podcast for convenient understanding

- Global attainment for your research

- Manuscript accessibility in different formats ( Pdf, E-pub, Full Text, Audio)

- Unceasing customer service

Track the below URL for one-step submission https://juniperpublishers.com/online-submission.php 